Article

\title{
Diffusion of Drone Journalism: The Case of Finland, 2011-2020
}

\author{
Turo Uskali ${ }^{1, *}$, Ville Manninen ${ }^{1,2}$, Pasi Ikonen ${ }^{1}$ and Jere Hokkanen ${ }^{1}$ \\ ${ }^{1}$ Department of Language and Communication Studies, University of Jyväskylä, 40014 Jyväskylän yliopisto, Finland; \\ E-Mails: turo.i.uskali@jyu.fi (T.U.), pasi.s.ikonen@jyu.fi (P.I.), jere.t.hokkanen@jyu.fi (J.H.) \\ 2 Innovation and Entrepreneurship InnoLab, University of Vaasa, 65200 Vaasa, Finland; \\ E-Mail: ville.manninen@univaasa.fi \\ * Corresponding author
}

Submitted: 30 March 2020 | Accepted: 8 June 2020 | Published: 27 July 2020

\begin{abstract}
This article details Finnish news organizations' adoption of drones for journalistic purposes from 2011 to 2020 . The theoretical starting point of the article is Rogers' (1962) diffusion of innovations theory, which explains how new ideas and technologies spread in societies. The main empirical data for the study were derived from a phone survey conducted among the 80 most popular newspapers in Finland. The findings reveal that drone journalism in Finland has already diffused from a few pioneering organizations to a large number of newsrooms, including regional, mid-sized newspapers. Most of the newspapers are either using in-house drones, buying commissioned images, or using both strategies. The frequency of use was found to be much higher for those newsrooms using their own drones. Finally, the article ponders possible explanations for different trajectories in the adoption of drones in various countries based on the Finnish case.
\end{abstract}

\section{Keywords}

aviation; drone journalism; Finland; news organizations; newspapers; visual journalism

\section{Issue}

This article is part of the issue "Journalism from Above: Drones, the Media, and the Transformation of Journalistic Practice" edited by Jonas Harvard (Mid Sweden University, Sweden), Mats Hyvönen (Uppsala University, Sweden) and Ingela Wadbring (Mid Sweden University, Sweden).

(C) 2020 by the authors; licensee Cogitatio (Lisbon, Portugal). This article is licensed under a Creative Commons Attribution 4.0 International License (CC BY).

\section{Introduction}

Over the last decade, easy-to-use, inexpensive, remotely piloted aircraft, unmanned aerial vehicles, and unmanned aerial systems - also known as camera droneshave entered the visual storytelling fields. Although newsrooms have long been able to use kites, balloons, planes, helicopters, cranes, and so forth to incorporate spectacular images and videos from a bird's eye view into their reporting, the drone is the first practical tool for aerial photography available to news organizations, regardless of their size or resources.

Drone journalism started internationally in the early 2000s with the help of amateurs, freelancers, and activists in various countries, with varying topics that included floods, demonstrations, and celebrities. After this pioneering testing period, between roughly 2010 and 2014, the largest and most resourceful newsrooms were among the first to invest in their own drone fleets and educate their photographers to become drone pilots. During this phase, the scope of drone activities advanced from isolated ad hoc cases to more continuous operations (Gynnild \& Uskali, 2018).

In Finland, the first news images and videos produced by camera drones were published in 2011, which aligns with the general drone journalism timelines in many other Western countries (Gynnild \& Uskali, 2018; Lauk, Uskali, Kuutti, \& Snellman, 2016). Yet there are many questions in this area. First, how has drone journalism diffused in the context of a single country? In particular, how are mid-sized or small newsrooms using drones, if at all? We find that small and mid-sized news- 
papers, in general, are under-researched in journalism studies. Similarly, news photographers have been gravely neglected in contemporary journalism research, which has mainly concentrated on the changes in the journalists' work (see, e.g., Greenwood, 2019).

To fill the current gap in drone journalism research, the present study focused on exploring the diffusion of drone journalism in Finland from 2011 onwards. The starting year of our inquiry is based on findings from previous studies (Lauk et al., 2016). The main research question of the current study is as follows:

RQ1: How many Finnish newspapers adopted drones for journalistic work between 2011 and 2020?

The Finnish media landscape has quickly digitized. Since 2014, Finns have spent more time on the Internet than with any other media (Ala-Fossi et al., 2018). However, newspapers still hold a distinctively strong position in Finland, as they have done historically (Jyrkiäinen, 2017). Newspaper publishing is the second largest media sector by revenue generation (after television), and seven of the ten largest media companies (by turnover) are newspaper publishers (Statistics Finland, 2020). An important feature of the Finnish newspaper industry is the persistent dominance of subscriptions over single-issue sales. In 2015 (i.e., the most recent data available), over 90 percent of all print copies were home delivered. This has lent Finnish newspapers financial stability and a license to focus on long-term quality over short-term sales.

In terms of journalistic production, newspapers are crucial in Finland. Although the public service broadcaster, Yleisradio, is the largest single employer of journalists in Finland, most private sector reporters work for various newspapers (Union of Journalists in Finland, 2019). The newspaper industry is also notably less concentrated than the radio and television industries (Ala-Fossi et al., 2018). Although the number of newspapers has been declining since 1990 , there are still close to 200 individual newspapers-in a country of some 5.5 million inhabitants (Finnish Newspapers Association, n.d.; Statistics Finland, 2020). This (relative) granularity of the field makes newspapers a more interesting object of innovation diffusion studies than, say, the highly centralized television sector. In terms of drone journalism, both liberal regulations and press freedom are vital prerequisites. Finland has consistently been at the top of the Press Freedom Index (Reporters Without Borders, 2020) and its drone regulations have been light, based on informing the authorities about drone activities but not asking for any permission or license.

In the next section, we will present the theoretical foundation of our enquiry based on a literature review in two research fields that we acknowledge as imperative for understanding the diffusion of drone journalism in Finland: innovation studies and research on changes in professional photojournalists' work conditions.

\section{Literature Review}

\subsection{Rogers' Diffusion of Innovations Theory}

Digital disruptions, financial crises, and constantly changing media consumption habits have exerted long-lasting negative influences on the journalism business, especially for newspapers (Jahangir \& Zhiping, 2015). For more than a decade, news media companies' typical strategy for responding to diminishing revenues has been to cut their workforce. For example, in Finland, this has been done with layoffs and early retirement pension packages (Nikunen, 2014).

However, many experts have emphasized that layoffs are not a sustainable solution for the future of journalism, instead suggesting more proactive measures. Pavlik (2013) argued that the key for journalism's viability is innovation; he defined innovation in news media as "the process of taking new approaches to media practices and forms while maintaining a commitment to quality and high ethical standards" (Pavlik, 2013, p. 183).

However, newsrooms often lack the necessary resources for creating innovations (see, e.g., Küng, 2015; Lowrey, 2012; Steensen, 2009). News organizations are designed first and foremost for effective, constant content production. Even if journalists' and photographers' work includes creative and innovative elements at the level of individual stories, these actors cannot innovate at the procedural or organizational levels. Therefore, we argue that rather than innovating, news organizations mainly adopt or adapt new technologies that they then incorporate into their work routines. This is also the case with drones.

Rogers' (1962) diffusion of innovations theory has been among the most influential theories for predicting how new technologies are communicated and adopted in societies and it has contributed significantly to the field of communication studies (Srivastava \& Moreland, 2012).

In journalism studies, the research on diffusion has focused on single platforms, such as journalists using Twitter (English, 2016; Muindi, 2018), TV stations using drones (Ferguson \& Greer, 2019), and on the adoption of major technological changes, including the use of computers for reporting (Davenport, Fico, \& Weinstock, 1996; Garrison, 2001; Maier, 2000). It has been applied to the emergence of user-generated content in news (Yeo, 2016), the study of multiform change-including technological, relational, and cultural aspects (Ekdale, Singer, Tully, \& Harmsen, 2015)-and the processes and influence of convergence (Micó, Masip, \& Domingo, 2013; Singer, 2004).

The innovation diffusion curve illustrates a wide variation in the time required by someone to adopt a new technology or service. The categories of adopters, based on the pace of adoption, are: (1) innovators; (2) early adopters; (3) early majority; (4) late majority; and (5) laggards (Rogers, 1962). 
In short, innovators are technology enthusiasts. They are the first to test and adopt new technology (Gershon, 2017). Early adopters follow them but tend to be more discerning in their adoption choices; they are crucial in "translating" the innovation and its worth into something the majority can understand (Gladwell, 2001). The early majority is also interested in acquiring new technology, but their rate of adoption is slower than those in the first two categories. Those representing the late majority are more cautious and resistant to change than those belonging to the aforementioned groups. Lastly, laggards are the ones that do not want to spend money or effort on new technology; they are the last to adopt an innovation.

We hypothesized that the diffusion of new technology is always gradual; therefore, the case of camera drones in Finnish newsrooms would be no different. In the current study, we applied Rogers' (1962) diffusion of innovations theory in a manner similar to Zhang and Feng's (2019) application in the context of data journalism in China. Their conclusion was that data journalism was not yet deeply rooted in China's journalistic tradition (Zhang \& Feng, 2019, p. 1297).

\subsection{Multiskilled and Precarious Photojournalists}

The role of photojournalists is crucial in drone adoption. Between 2015 and 2018, the use of drones increased from three percent to eight percent among participants in the World Press Photo Contest (Hadland, Campbell, \& Lambert, 2018). Major influences affecting the work of photojournalists from the 2000s onwards include the changing economic situation of media organizations, adoption of new technology, shifts in newsrooms' use of photographs and video, and the requirement of multiskilling.

Redundancies in US newsrooms between 2000 and 2012 led to 43 percent job cuts for photographers, artists, and videographers, exceeding those of their reporter and editor colleagues (Anderson, 2013). Among the participants in the World Press Photo Contest, the number of professionals working full-time in photography decreased from 74 percent to 59 percent between 2015 and 2018 (Hadland et al., 2018). Finnish newsrooms also faced several substantial layoffs between 2009 and 2015 (Atarah, 2012; Ilta-Sanomat, 2014; Yle, 2015). Unfortunately, there are no official statistics on the number of photojournalists in Finland. There are about 8,400 working journalists (Union of Journalists in Finland, 2019), whereas the Finnish Association of Photojournalists has only 254 members (I. Launiala, personal communication, 9 March 2020).

In the 1990s, a shift from using film cameras to digital ones changed photojournalists' work routines (Fahmy \& Smith, 2003). Later, Klein-Avraham and Reich (2016) noted the weakened professional status of photojournalists. One reason for this was so-called deskilling: automatic cameras and software, such as Photoshop, allowed almost anyone to capture and distribute decent- quality photographs. A study on Czech photojournalists noted the increased workload and decreased degree of specialization (Štefaniková \& Láb, 2016). Notably, newsrooms have used more amateur photographs and video in their news reports because of their low cost and timeliness (Andén-Papadopoulos \& Pantti, 2011; Mäkelä, 2014). In part, photographers have either been replaced by multiskilled multimedia journalists or have had to undertake responsibilities that did not exist before, such as producing audio, video, and multimedia (Robinson, 2011; Štefaniková \& Láb, 2016; Yaschur, 2012). Because of these pressures and many layoffs during the last decade, photojournalists are in a precarious position (Mortensen, 2014).

Multiskilling is both a threat and a possibility for enhancing photojournalists' professional status. Rapid technological evolution has been a cause of stress internationally (Hadland, Campbell, \& Lambert, 2015). In a study on Finnish photojournalists in 2007-2008, Mäkelä (2014) noted that most participants saw multiskilling as a threat to their professional identity.

Drones represent a new tool that requires both technical expertise and the knowledge of ethics and regulations of drone use. On the one hand, learning to use drones is yet another arduous task for many. On the other hand, this new technology might strengthen the professional status of photojournalists by giving them preeminence over amateurs (Klein-Avraham \& Reich, 2016), enabling professionals to acquire new skills that could help them career-wise (Greenwood \& Reinardy, 2011).

\section{Method}

The current study is based on two rounds of telephone surveys of Finnish newspapers. The first round $(n=28)$ was conducted in summer 2019, and it collected extensive data on drone acquisition and use. The second round ( $n=52$ ) was conducted in early 2020 , and although it included more newsrooms, it only sought to gather data on drone acquisition. Combined, the data provide a comprehensive overview of drones' diffusion into newspaper newsrooms and qualitative information on their use.

Additional qualitative data on drone use was collected by interviewing the representatives of five droneusing newsrooms in spring 2020. These five newsrooms were selected from the latter survey sample $(n=52)$ to represent newspapers of different sizes and geographical regions.

The full sample $(\mathrm{N}=80)$ was designed to cover all of Finland's major newspapers. First, we compiled two lists of Finland's leading newspapers. One list contained the 50 largest newspapers by print circulation. The second list comprised the 50 largest newspapers by reach (i.e., combined print and digital readership). Merging these two lists produced a sample of 80 newspapers. This composite sampling was chosen to ensure the inclusion of all relevant newspapers. Using only one of the two lists would skew the picture of Finland's newspaper sector. 
For example, the country's two leading tabloids, I/talehti and I/ta-Sanomat, have opted out of the print circulation audit. In contrast, some regional newspapers have a relatively weak online presence despite their respectable print circulation.

The newspapers in our sample were contacted by telephone and failing that, by email. Contact was preferably made with each newspaper's photo editor, but in some cases, only an individual photographer, news editor, or the editor-in-chief completed the survey. The first round of surveys and supplementing five interviews asked about the time of drone acquisition, the use of outside drone footage, and the frequency of the newsrooms' drone use. In the second round, the respondents were asked to indicate whether the newsroom operated its own drone fleet and, if so, when the drones were first acquired. This information was collected by year quarters. Some respondents were able to cite an exact month or even date of acquisition, but most recalled the time frame only in approximations, usually as a season in a particular year (e.g., "spring of 2019" or "at the end of 2016"). Hence, we recorded the information in similar terms. Most respondents could recall this information with apparent ease, while some had to confirm the time from archival records or their colleagues. Sometimes, definitive answers could not be found, and in these (few) cases, we recorded the earliest year quarter the respondent was certain drones were in the newsroom's possession. Although relying on the respondents' recall can be fallible, the results are likely close to the objective reality: The question is unambiguous and the time frame short (for most newsrooms, less than five years).

Data on when newsrooms adopted freelancer-based drone use was not collected because of methodological difficulties. It would be near impossible to determine when freelance drone services first became an acknowledged option at different newsrooms. Simply recording the first use of commissioned drone footage would be inaccurate as well: A one-off use of drone imagery does not equal adoption in anything but a superficial way. Only a massive content analysis could reveal when drone material has become a newsroom staple. In comparison, newsrooms' acquisition of drones is a relatively clear-cut indication of drones' perceived utility.

Having drones in a newsroom's inventory was defined as having them available without the need to schedule their use with freelancers or affiliated newsrooms. This type of drone use implies a modicum of commitment to drone use, one usually involving the allocation of resources for the devices' purchase and staff training. Many newspapers make use of drone footage by commissioning it from freelancers or from better-equipped affiliates; this was interpreted as newsrooms 'not having' their own drones. Although these newspapers acknowledge drones' usefulness in select situations, they do not-per our definition-see drones as a necessity for their daily operation. A total of 24 newspapers indicated this to be their drone-use strategy. In addition to the di- chotomy between the 'haves' and 'have-nots,' one newspaper permanently houses drones owned by the newspaper's photographers. This situation was interpreted as the newspaper 'having' drones.

\section{Results}

A total of 24 newsrooms of the 80 surveyed newspapers operate their own drone fleets (30 percent). Additional 30 percent ( 24 newspapers) indicated they have, if need be, access to drone footage through freelancers or affiliated newsrooms. The remaining 32 newspapers ( 40 percent) showed no interest in drone use although it is almost certain that they, too, could purchase drone services from outside the newsroom. Only one of the surveyed newspapers had once had its own drone but did not have one at the time of contact. Even in this case, the respondent indicated that the newsroom was looking to replace the drone, which had been transferred within the company to a different location.

In terms of a timeline, Helsingin Sanomat was the first Finnish newspaper to start using their own camera drones. The newspaper's drones flew their first mission in mid-January 2012. For over two years, it was the only newspaper in our sample to operate its own drone fleet. It was joined in the second quarter of 2014 by the national tabloid, I/ta-Sanomat, and the regional news daily, Karjalainen. From there on, drones began to diffuse into other large and mid-sized newspapers. The first smaller newspaper to acquire its own drones was Raahen Seutu, a tri-weekly regional newspaper with a circulation of a little over 6,000 copies; its history with drones began in the third quarter of 2017. The rate of drone adoption appears to have been steady since the trend caught on in 2014. Figure 1 shows how the ownership of camera drones evolved from 2011 to 2020.

Our survey results show that Finland's seven largest newspapers deploy their own drones. Further, of the 15 largest newspapers, only three have resisted the trend. The sample's mid-range, which consists of regional and large local newspapers, is mixed: about half of them have their own drones. The bottom third of our sample is consistently drone free. This suggests a very straightforward diffusion: drones were first adopted by larger and betterresourced newspapers, with smaller organizations following suit within a few years. At the time of the study, at-the-ready drone fleets appeared to be a must-have for leading newspapers, optional for mid-sized newspapers and unnecessary for small newspapers. The use of freelancers' or affiliates' drones was referenced rather evenly throughout the sample. This implies that drones' value to journalism can be recognized-or dismissedregardless of newsroom resources.

So far, the rate of drone diffusion has been steady. Our survey, however, indicates that most droneless newsrooms are hesitant-or even opposed-to acquiring them. Some respondents said that they are waiting to see what changes the new EU regulations (being drafted 
$40 \%$

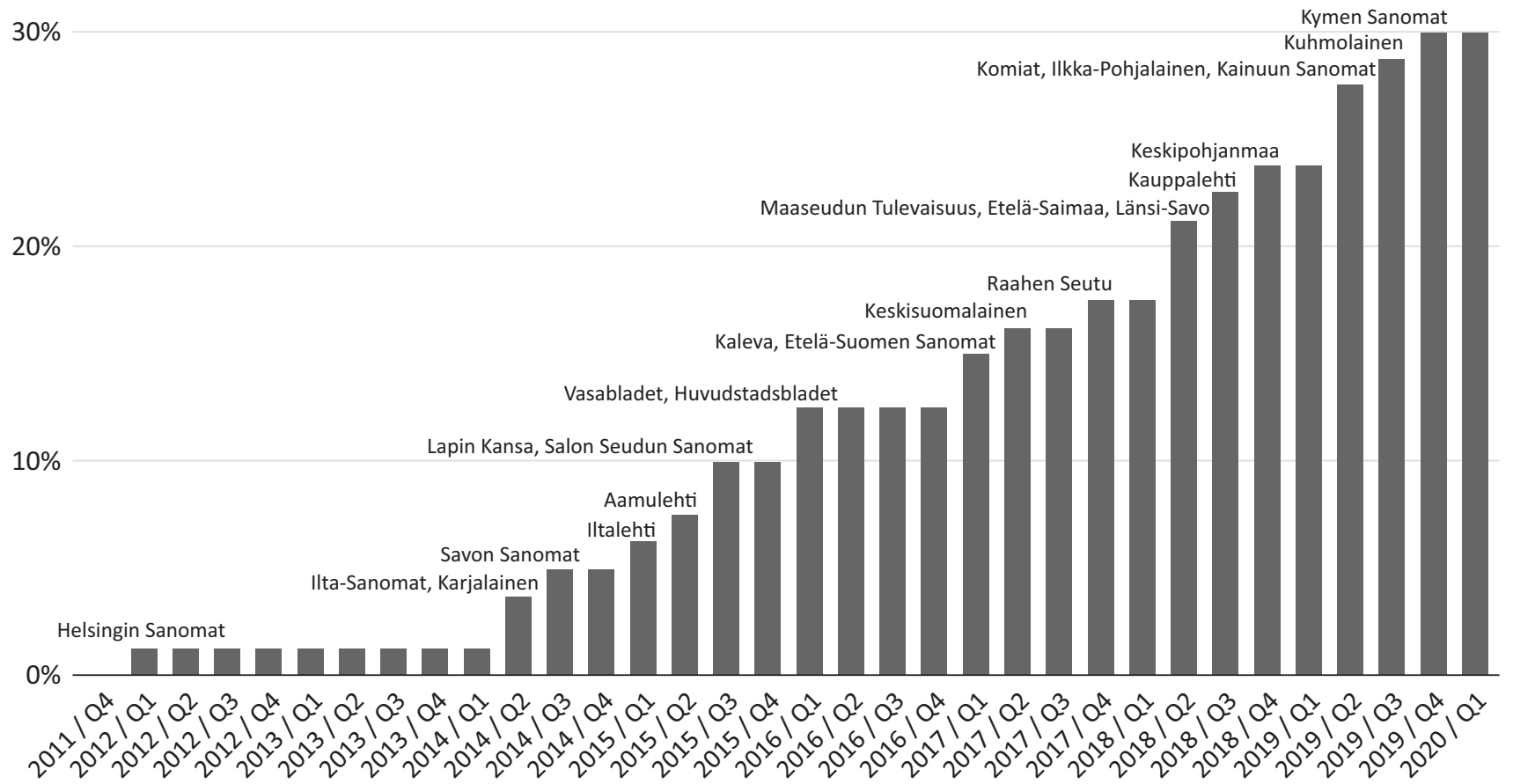

Figure 1. Share of drones and time of acquisition among Finland's 80 leading newspapers, 2011-2020.

at the time of writing) bring, while others suggested that they do not need drones or that their occasional needs can be met through external commissioning.

The first round of surveys $(n=28)$ supplemented with interviews $(n=5)$ collected information on drone acquisition, use of outside footage, and the frequency of drone use by asking for an estimate. Of the 33 newsrooms included in this sample, 19 were using their own drones, 12 were using drone footage through freelancers or affiliated newsrooms, and two were not using drone footage at all.

Those equipping their own drones used them more frequently than the ones acquiring footage from outside sources. Newspapers owning drones flew them daily (3), weekly (12), or occasionally (4), whereas the ones employing freelancers used drone footage only occasionally (6) or very rarely (6). Adding this up, of the 31 newsrooms that did use drone footage, three newsrooms were using them daily, 12 weekly, ten occasionally, and six very rarely.

As for the type of use, common themes in drone footage were land use planning and construction, festivals, and nature. However, these data were not collected systematically from the newspapers. The survey and interviews responses also hint at very varied use, from quick and simple high-altitude shots from one specific position, to more complex video rolls like pans and tracking shots.

\section{Discussion and Conclusion}

In the current article, we have looked at the diffusion of drones among Finnish newspapers. Despite early experiments, their widespread adoption did not begin until mid2014. Drone journalism in Finland has diffused from a few pioneering organizations to a larger number of newsrooms, including regional and mid-sized newspapers.

At the turn of 2020s, about two-thirds of the newspapers in our sample were using camera drones. Thirty percent use their own drones and equally as many commission drone footage from outside the newsroom. Although we did not explicitly ask about it, many respondents noted that their newsrooms had been exposed to drones through the enthusiasts in their employ. Specifically, freelancers, summer interns, or staff photographers brought their personal drones to the office to show and use. For example, the first sampled newspaper to acquire drones did so at the initiative of their dronehobbyist photographers. Thus, it is likely that the newsrooms were familiar with drones and their journalistic possibilities, but the uncertainty around their regulatory status was too much of a deterrent for most until 2014.

The newsrooms in our study use drone footage according to two strategies: through buying their own drones or commissioning freelancers. Some supplement in-house material with footage bought outside the organization. Both strategies are valid and enable using 
high-quality aerial images and video in reporting. For example, in Spain, Fernández-Barrero (2018) noted that major media companies were mainly preferring to outsource drone services because of tight regulation, the cost of buying drones, limitations of image quality, and many other reasons. The current situation in Finland seems quite different. Our study of 33 Finnish newspapers shows that newsrooms in possession of drones use drone footage more often than those relying on freelancers. In our survey, none of the newsrooms using the freelancer strategy acquired drone footage daily or even weekly. Ferguson and Greer (2019) studied the adoption of drones in 94 local TV stations in the US and found that the stations that use drones use them only to a moderate degree, a mean figure of 2.28 on a scale of 0 to $5(0=$ not at all, $5=$ daily). Our findings hint at a similar direction: most newspapers use their drones weekly.

Having a drone (or several) at the newsroom probably makes it much easier to acquire aerial footage, although having a drone increases the costs for the newsroom: the drone(s) must be bought (prices for basic models are around 1000-2000€) and repaired in case of damage. In Finland, insurance is also mandatory. The photographers must be trained both for operating the aerial vehicle and for the ethical and legal aspects of flying. Therefore, choosing to adopt drones via freelancers may prove to be a viable option if the predicted utility of inhouse drones does not match the costs.

As per Rogers' (1962) model, drones were first picked up by innovators-in this case, technology-enthusiast photographers. Because of their increasingly precarious professional status, upskilling themselves to drone pilots was an attractive route for improved occupational prospects. At the next stage, early adopters followed the budding trend. In the case of Finland and drone journalism, large, well-resourced newsrooms were the first to adopt drones as soon as the fear over legal repercussions of their use was dispelled. At the next crucial step, early adopters "translated" (Gladwell, 2001)-that is, made salient - the value of drones. By pioneering the forms and practices of drone journalism, they set an actionable example for their peers. After seeing the early adopters successfully use drones for journalism, the early majority-some mid-sized and small newspapersbegan adopting drones in 2017. Simultaneously, drones were becoming more affordable, reliable, and easier to pilot. At this point, drone journalism in Finland seems to be reaching the late majority. Some apparent laggards were also present in our sample-those loath to adopt innovations until they are unavoidable.

Next, we will examine how the results of the Finnish case compare with the development of drone journalism elsewhere. First, regulation seems to play an essential role in terms of drone journalism. Compared with other countries, for example, Sweden and the US, Finland received its own drone act quite early; the Finnish drone rules came into effect in 2015 (Finnish Aviation Act, 2014), in Sweden in 2017, and in the US in 2018. Without a permissive legal environment, many news organizations are hesitant to adopt drones. The environment particularly affects the late majority and the laggards because these groups are reluctant to spend their relatively scarce resources on an innovation if there is any uncertainty about the benefits of doing so (Rogers, 1962).

So far, about 40 countries have either declared a total ban on or have heavily restricted the use of camera drones. For example, the US and Sweden have temporarily banned the use of camera drones. In the US, drone journalism education was halted by the authorities from 2013 to 2016. In Sweden, a total ban on using drones for journalism lasted from autumn 2016 to summer 2017 (Uskali \& Gynnild, 2018). Finland has never heavily restricted or banned the use of drones in journalism, which has enabled their diffusion.

Second, even minor incidents have had a nationwide influence on how the diffusion of drones evolves. Based on previous research on drone journalism, we can list several cases where only one incident or simply the threat of an incident has triggered a nationwide ban on the use of camera drones: Nepal in 2015, Kenya in 2015, Thailand in 2015, and Sweden in 2016. For example, in the Nepalese case, in the aftermath of a devastating earthquake, as powerful drone videos of the ruins of old buildings in Kathmandu began circulating online, the authorities instituted a nationwide drone ban, mainly to safeguard their country's image and tourism industry (Uskali \& Gynnild, 2018).

Therefore, the concept of the 'key incident' is introduced as another complementary explanation for why the diffusion of drone journalism practices have had different trajectories, even in neighboring democratic countries such as Finland and Sweden.

'Key incident' refers to a news event that stimulates public discussions about the ethical use of new technology. Key incidents lead to watershed moments that either strengthen the adoption of a new device or service, hinder the process, or prohibit the use of the device or service. The result of the key incident depends on the conclusion of the public debate and on the decisions made by the authorities and policymakers.

In the literature, the terms 'focusing event' (Birkland, 1998) and 'key event' (Zerback, Reinemann, Van Aelst, \& Masini, 2020) have been used to describe certain impactful happenings that have had, for example, an agendasetting influence in societies. The concepts of focusing event and key event are based on large-scale tragic news. For example, natural disasters and industrial accidents are defined as focusing events (Birkland, 1998), and the Lampedusa shipwreck disaster in 2013 was a key event for immigration reporting in Italy but not in Germany or Belgium (Zerback et al., 2020). A key incident may also be something negative, or it may be neutral or even positive. In addition, Wood (2006) conceptualized the term 'tipping event' which includes minor or even nonexistent incidents (i.e., speculation, fear, or thoughts) that might trigger a change. 
Our long-term observations highlighted one case that could be defined as a key incident in terms of drone journalism in Finland: the Sysmä small plane crash in May 2013 (e.g., Ilta-Sanomat, 2013a; Yle, 2013). This plane crash pitted drone pilots against authorities in a brief but dramatic standoff. The initial signal was that drones' journalistic use could be interpreted as unlawful and be met with gunfire. This kind of publicity, even without an official resolution, could have created a perception of drones as a liability to their pilots and a danger to society. However, the incident reached a public conclusion: an authoritative figure articulated the legal and ethical boundaries of drone journalism, to which the police acquiesced by issuing a public apology (e.g., Ilta-Sanomat, 2013b; MTV3, 2013).

At the time of the key incident, no special drone regulation existed in the Finnish aviation law. Although there were no immediate regulatory effects, the widely publicized and discussed incident had a pivotal impact on the legitimacy of drone journalism. We argue that both the early test of the limits of drone journalism, the key incident in 2013, and the early crafted and light drone regulation were vital for the constantly increasing drone adoption in Finnish newspapers. The current regulatory status of drones is permissive, but new EU wide drone regulations are slated to come into force in mid-2020. Starting from July 2020, a common EU regulation will replace all national drone rules, and a drone pilot needs authorization from the state's registry (European Union Aviation Safety Agency, 2020). This contributes to an air of uncertainty. The diffusion of drones among Finnish newspapers might be on a hiatus while journalists anticipate the new regulations. A follow-up study is needed to monitor and analyze the implications of the new EU law for drone journalism in Finland and elsewhere.

The current study has some limitations, and further studies are needed. Although our data cover a good portion of Finnish newspapers, our survey is limited in its depth. The survey of 80 newspapers inquired about drone ownership (or the use of outsourced footage) and does not contain more specific information on how drones are used. Our smaller sample $(n=33)$ illustrates the frequency of drone use. Further questions remain. These include more specific details on drone use, the effects of legislation from the viewpoint of newspapers, and reasons for (and against) acquiring drones for the newsroom. Also, the status of news photographers should be studied in the light of drone adoption. How has this development affected their work?

The regulatory environment for drone journalism internationally is heterogeneous. Therefore, the key incidents behind divergent developments should be studied and compared with each other. Such comparative research could reveal different patterns of incident, response, and innovation diffusion-perhaps dispelling some deterministic views on media systems and technological diffusion. An international comparison could well illustrate the effect that drone aviation legislation has on the adoption of drones for journalistic use. There is also a need for localized investigations, such as case studies on those outlier large newsrooms that have not adopted drones along with their peers. How drones are actually used is a rarely studied topic and deserves further attention. Data on how much drone footage is used could be collected, and barriers for the adoption of drones should be looked into. Studies comparing owning and commissioning strategies would also help in understanding their use more comprehensively. Furthermore, the professional precarity of photojournalists should be studied in depth.

\section{Acknowledgments}

We thank the Media Industry Research Foundation of Finland for funding this research. We are also grateful for all the blind reviewers that helped us develop this article into its current form.

\section{Conflict of Interests}

The authors declare no conflict of interests.

\section{References}

Ala-Fossi, M., Álen-Savikko, A., Grönlund, M., Haara, P., Hellman, H., Herkman, J., . . Koskenniemi, A. (2018). Media-ja viestintäpolitiikan nykytila ja mittaaminen [Media and communication policy nowadays and measuring]. Helsinki: Ministry of Transport and Communications. Retrieved from http://urn.fi/URN:ISBN: 978-952-243-548-4

Andén-Papadopoulos, K., \& Pantti, M. (2011). Amateur images and global news. Bristol: Intellect Books.

Anderson, M. (2013). At newspapers, photographers feel the brunt of job cuts. Pew Research Center. Retrieved from https://www.pewresearch.org/facttank/2013/11/11/at-newspapers-photographersfeel-the-brunt-of-job-cuts

Atarah, L. (2012). Staff reduction in media houses affects quality of journalism. The Union of Journalists in Finland. Retrieved from https://journalistiliitto.fi/ en/staff-reduction-in-media-houses-affects-qualityof-journalism

Birkland, T. A. (1998). Focusing events, mobilization, and agenda setting. Journal of Public Policy, 18(1), 53-74.

Davenport, L., Fico, F., \& Weinstock, D. (1996). Computers in newsrooms of Michigan's newspapers. Newspaper Research Journal, 17(3/4), 14-28. https://doi. org/10.1177/073953299601700302

Ekdale, B., Singer, J. B., Tully, M., \& Harmsen, S. (2015). Making change: Diffusion of technological, relational, and cultural innovation in the newsroom. Journalism \& Mass Communication Quarterly, 92(4), 938-958. https://doi.org/10.1177/1077699015596337

English, P. (2016). Twitter's diffusion in sports journalism: Role models, laggards and followers of the social me- 
dia innovation. New Media \& Society, 18(3), 484-501. https://doi.org/10.1177/1461444814544886

European Union Aviation Safety Agency. (2020). Civil drones (Unmanned aircraft). European Union Aviation Safety Agency. Retrieved from https://www. easa.europa.eu/easa-and-you/civil-drones-rpas

Fahmy, S., \& Smith, C. Z. (2003). Photographers note digital's advantages, disadvantages. Newspaper Research Journal, 24(2), 82-96. https://doi.org/ $10.1177 / 073953290302400206$

Ferguson, D. A., \& Greer, C. F. (2019). Assessing the diffusion of drones in local television news. Electronic News, 13(1), 23-33. https://doi.org/10.1177\% 2F1931243119829430

Fernández-Barrero, M. A. (2018). Journalism and drones: Challenges and opportunities of the use of drones for informative narration in Spain. Doxa Comunicación, 26, 35-58.

Finnish Aviation Act, 864 § 9, 57 and 70 (2014). Retrieved from https://arkisto.trafi.fi/filebank/a/1444223591/ 7ded5988558660d38599203de96117fe/18706OPS_M1-32_RPAS_eng.pdf

Finnish Newspapers Association. (n.d.). Finnish Newspapers Association. Finnish Newspapers Association. Retrieved from https://www.sanomalehdet.fi/ sanomalehtien-liitto/finnish-newspapersassociation

Garrison, B. (2001). Diffusion of online information technologies in newspaper newsrooms. Journalism, 2(2), 221-239. https://doi.org/10.1177/ 146488490100200206

Gershon, R. A. (2017). Digital media and innovation: Management and design strategies in communication. London: Sage Publications.

Gladwell, M. (2001). The tipping point: How little things can make a big difference. London: Abacus.

Greenwood, K. (2019). Photojournalism and photojournalists. In T. P. Vos \& F. Hanusch (Eds.), The international encyclopedia of journalism studies (pp. 1182-1194). Hoboken, NJ: Wiley-Blackwell.

Greenwood, K., \& Reinardy, S. (2011). Self-trained and selfmotivated: Newspaper photojournalists strive for quality during technological challenges. Visual Communication Quarterly, 18(3), 155-166. https://doi. org/10.1080/15551393.2011.599285

Gynnild, A., \& Uskali, T. (2018). The first wave of drone journalism: From activist tool to global game changer. In A. Gynnild \& T. Uskali (Eds.), Responsible drone journalism (pp. 15-35). London: Routledge.

Hadland, A., Campbell, D., \& Lambert, P. (2015). The state of news photography: The lives and livelihoods of photojournalists in the digital age. Oxford: Reuters Institute for the Study of Journalism. Retrieved from https://reutersinstitute.politics.ox.ac.uk/ourresearch/state-news-photography-lives-andlivelihoods-photojournalists-digital-age

Hadland, A., Campbell, D., \& Lambert, P. (2018). The state of news photography: The lives and liveli- hoods of photojournalists in the digital age. Amsterdam: World Press Photo. Retrieved from https:// www.worldpressphoto.org/programs/explore/ research/the-state-of-news-photography-2018/ 28643

Ilta-Sanomat. (2013a, May 3). Sysmän lentoturmassa kuoli kaksi [Two died in a plane accident at Sysmä]. I/ta-Sanomat. Retrieved from https://www.is.fi/ kotimaa/art-2000000609258.html

Ilta-Sanomat. (2013b, May 6). Poliisi kuumeni kuvaajalle Sysmässä-kuvauslennokki olisi ammuttu alas [A police was heated up because of a photographer at Sysmä-A drone would have been shot down]. IltaSanomat. Retrieved from https://www.is.fi/kotimaa/ art-2000000610029.html

Ilta-Sanomat. (2014, December 6). Ylen yt-mylläkkä: Yksikään pomo ei joutunut lähtemään-reilusti yli puolet potkut saaneista yli 50-vuotiaita [Hassle about the co-operation procedure at the Finnish Broadcasting Corporation: Not a single boss needed to goOver half of those who were sacked were over 50 years]. Ilta-Sanomat. Retrieved from https://www.is. fi/kotimaa/art-2000000845543.html

Jahangir, K., \& Zhiping, W. (2015). The role of dynamic capabilities in responding to digital disruption: A factorbased study of the newspaper industry. Journal of Management Information Systems, 32(1), 39-81. https://doi.org/10.1080/07421222.2015.1029380

Jyrkiäinen, J. (2017). Sanomalehdistö [The Press]. In K. Nordenstreng \& H. Nieminen (Eds.), Suomen mediamaisema [The Finnish media landscape] (pp. 65-117). Tampere: Vastapaino.

Klein-Avraham, I., \& Reich, Z. (2016). Out of the frame: A longitudinal perspective on digitization and professional photojournalism. New Media \& Society, 18(3), 429-446. https://doi.org/10.1177/ 1461444814545289

Küng, L. (2015). Innovators in digital news. London: I.B. Tauris.

Lauk, E., Uskali, T., Kuutti, H., \& Snellman, P. (2016). Droonijournalismi: Kauko-ohjattavien kamerakoptereiden toimituskäyttö [Drone journalism: Utilizing remotely piloted aircrafts (RPA) in journalistic purposes]. Jyväskylä: University of Jyväskylä. Retrieved from https://jyx.jyu.fi/dspace/handle/ $123456789 / 51821$

Lowrey, W. (2012). Journalism innovation and the ecology of news production: Institutional tendencies. Journalism \& Communication Monographs, 14(4), 214-287. https://doi.org/10.1177/ 1522637912463207

Maier, S. R. (2000). Digital diffusion in newsrooms: The uneven advance of computer-assisted reporting. Newspaper Research Journal, 21(2), 95-110. https:// doi.org/10.1177/073953290002100208

Mäkelä, J. (2014). Rethinking photojournalism: The changing work practices and professionalism of photojournalists in the digital age. Nordicom Re- 
view, 35(2), 91-104. https://doi.org/10.2478/nor2014-0017

Micó, J. L., Masip, P., \& Domingo, D. (2013). To wish impossible things*: Convergence as a process of diffusion of innovations in an actor-network. International Communication Gazette, 75(1), 118-137. https://doi.org/10.1177/1748048512461765

Mortensen, T. M. (2014). Blurry and centered or clear and balanced? Citizen photojournalists and professional photojournalists' understanding of each other's visual values. Journalism Practice, 8(6), 704-725. https://doi.org/10.1080/17512786.2014. 892703

MTV3. (2013). Sysmän koneturma: Poliisi pyysi anteeksi ampumispuheitaan toimittajilta [The Sysmä plane accident: The police apologised the journalists for the talks about shootings]. MTV Uutiset. Retrieved from https://www.mtvuutiset.fi/ artikkeli/sysman-koneturma-poliisi-pyysi-anteeksiampumispuheitaan-toimittajilta/1912802

Muindi, B. (2018). Negotiating the balance between speed and credibility in deploying Twitter as journalistic tool at the Daily Nation Newspaper in Kenya. African Journalism Studies, 39(1), 111-128. https:// doi.org/10.1080/23743670.2018.1445654

Nikunen, K. (2014). Losing my profession: Age, experience and expertise in the changing newsrooms. Journalism, 15(7), 868-888. https://doi.org/10.1177/ 1464884913508610

Pavlik, J. V. (2013). Innovation and the future of journalism. Digital Journalism, 1(2), 181-193. https://doi. org/10.1080/21670811.2012.756666

Reporters Without Borders. (2020). 2020 world press freedom index. Reporters Without Borders. Retrieved from https://rsf.org/en/ranking

Robinson, S. (2011). Convergence crises: News work and news space in the digitally transforming newsroom. Journal of Communication, 61(6), 1122-1141. https://doi.org/10.1111/j.1460-2466.2011.01603.x

Rogers, E. (1962). Diffusion of innovations. New York, NY: Free Press of Glencoe.

Singer, J. B. (2004). Strange bedfellows? The diffusion of convergence in four news organizations. Journalism Studies, 5(1), 3-18. https://doi.org/10.1080/ 1461670032000174701

Srivastava, J., \& Moreland, J. J. (2012). Diffusion of innovations: Communication evolution and influences. The Communication Review, 15(4), 294-312. https:// doi.org/10.1080/10714421.2012.728420
Statistics Finland. (2020). Mass media statistics. Statistics Finland. Retrieved from http://www.stat.fi/til/jvie/ index_en.html

Steensen, S. (2009). What's stopping them? Towards a grounded theory of innovation in online journalism. Journalism Studies, 10(6), 821-836.

Štefaniková, S., \& Láb, F. (2016). Transformation of photojournalism practice in the Czech Republic in the age of digital technology. Journalism, 19(2), 234-251. https://doi.org/10.1177/1464884916663622

Union of Journalists in Finland. (2019). Jäsentilastoja [Membership statistics]. Union of Journalists in Finland. Retrieved from https://journalistiliitto.fi/fi/ liitto/tietoa-jasenistamme/jasentilastoja

Uskali, T., \& Gynnild, A. (2018). Three scenarios of responsible drone journalism. In A. Gynnild \& T. Uskali (Eds.), Responsible drone journalism (pp. 85-94). London: Routledge.

Wood, R. S. (2006). Tobacco's tipping point: The master settlement agreement as a focusing event. Policy Studies Journal, 34(3), 419-436. https://doi.org/ 10.1111/j.1541-0072.2006.00180.x

Yaschur, C. (2012). Photojournalists enjoy web work, additional autonomy. Newspaper Research Journal, 33(1), 71-85. https://doi.org/10.1177/07395329120 3300106

Yeo, T. E. D. (2016). Communicating legitimacy: How journalists negotiate the emergence of user-generated content in Hong Kong. Journalism \& Mass Communication Quarterly, 93(3), 609-626. https://doi.org/ $10.1177 / 1077699016628823$

Yle. (2013). Sysmässä maahan syöksynyt pienkone tallentui lintukuvaajan kameraan [The plane that crashed at Sysmä was recorded by a bird photographer]. Yle. Retrieved from https://yle.fi/uutiset/3-6622250

Yle. (2015). Sanoman yt-tulos: 241 tehtävää loppuu [The result of the co-operation procedure at the Sanoma Corporation: 241 work assignments will be terminated]. Yle. Retrieved from https://yle.fi/uutiset/38390654

Zerback, T., Reinemann, C., Van Aelst, P., \& Masini, A. (2020). Was Lampedusa a key event for immigration news? An analysis of the effects of the Lampedusa disaster on immigration coverage in Germany, Belgium, and Italy. Journalism Studies, 21(6), 748-765. https://doi.org/10.1080/1461670X.2020.1722730

Zhang, S., \& Feng, J. (2019). A step forward? Journalism Studies, 20(9), 1281-1300. https://doi.org/10.1080/ 1461670X.2018.1513814

\section{About the Authors}

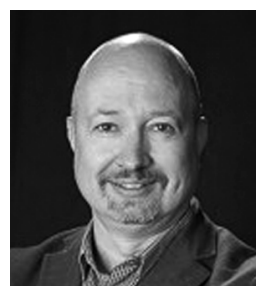

Turo Uskali (PhD) is an Associate Professor and the Head of Journalism program at the University of Jyväskylä, Finland. He heads several research projects focusing on innovations in journalism. Uskali has authored, edited, and coedited seven books about the new forms and practices of journalism and contributed to about 50 research articles and book chapters. 

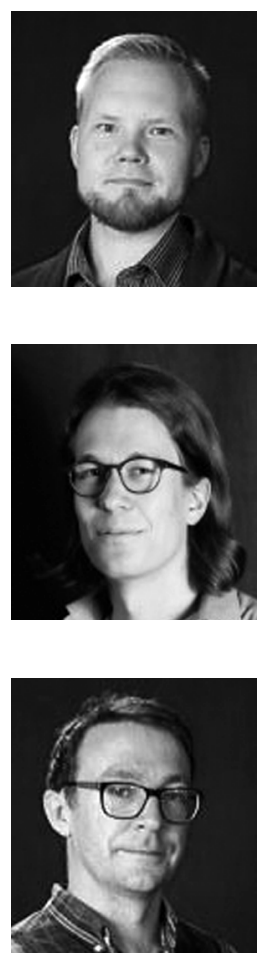

Ville Manninen (PhD) is a Researcher, both at the University of Vaasa and University of Jyväskylä, and he also teaches communications in Vaasa. His background is in journalism studies, with most of his work dealing with trust in online journalism and media plurality.

Pasi Ikonen (MA) has worked on numerous research projects on journalism at the Department of Language and Communication Studies at the University of Jyväskylä, Finland. He has studied drones and virtual reality and edited the world's leading news service of journalism research, journalismresearchnews.org.

Jere Hokkanen (MA) graduated in 2019 and is currently doing a PhD on City Planning. He is interested in applying comparative satellite data to study construction projects related to his topic. He has worked as a Research Assistant in Journalism in three different projects, one being Turo Uskali's, and in other fields such as applied linguistics. 